\title{
Investigation of Thymidylate Synthase Induction in Colorectal Tissues after Administration of Anticancer Drug, Fluorinated Pyrimidine Fluoride Derivatives
}

\section{ORIGINAL ARTICLE Annals of Cancer Research and Therapy}

\author{
Kitaro Futami · Sumitaka Arima*11.
}

\begin{abstract}
Patients with colorectal carcinoma were treated with UFT and Tegafur for 7 days repeated ( $600 \mathrm{mg}$ per day), and 5FU concentrations in tissues and inhibition rate of Thymidylate Synthase (TS) were compared. As a control, total amounts of TS were determined in tissues from patients who did not receive any drug. Total amounts of TS were compared between UFT or Tegafur group and control group.

Both 5-FU concentration and inhibition rate of TS in tumor tissues were significantly higher in UFT group than Tegafur group.

Total amounts of TS in tumor tissues, normal mucous membranes, and lymph nodes were significantly higher in patients treated with drugs than patients who did not receive any drug. Particularly, high level of TS was induced in patients treated with UFT. Relationship between total TS in tumor tissues and inhibition rate of TS were then studied. Inhibition rate of TS remained 50 to $60 \%$ regardless of total TS.

Ann Cancer Res Ther 2 (1) : 101-104, 1993 / Received 21 Dec 1992

Key words : TS induction, TS inhibition rate, Colorectal cancer, UFT
\end{abstract}

It is generally believed that 5 -FU (one of pyrimidine fluoride derivatives) manifests antitumor activity primarily by inhibiting DNA replication by inhibiting Thymidylate Synthase (TS) by way of its active metabolite, 5-fluorodeoxyuridinemonophosphate (FdUMP)". UFT is a masked compound of 5-FU' ${ }^{2)}$, an exciting biochemical modulator, and one of the most widely used antitumor drugs for gastrointestinal carcinoma today. It has been reported that high levels of 5-FU concentrations in tumor tissues were achieved after the administration of UFT ${ }^{3}$ and that TS was greatly inhibited from basic and clinical studies, ${ }^{4}$ ). Higher levels of TS were detected in tumor tissues than normal mucous membranes, and it has been pointed out that TS was induced in tissues after the administration of pyrimidine fluoride derivatives from basic science research $^{6}{ }^{77}$. The authors investigated 5-FU concentration and inhibition rate of TS in tissues after the repeated administration of UFT and Tegafur in patients with colorectal carcinoma and monitored TS activity as compared with cases who did not receive any drug as a control.

\section{Subjects and methods (Fig 1)}

Forty-eight cases with colorectal carcinoma were studied. All cases had resection of colorectal carcinoma. Thirty-seven cases were treated with drugs, i.e. UFT or Tegafur was administered repeatedly and orally for 7 days ( $600 \mathrm{mg}$ daily, $200 \mathrm{mg}$ per administration, 3 times a

\footnotetext{
* Department of Surgery, Chikushi Hospital, Fukuoka University, 377-1 Zokumyoin, Chikushino City, Fukuoka 818, Japan
}

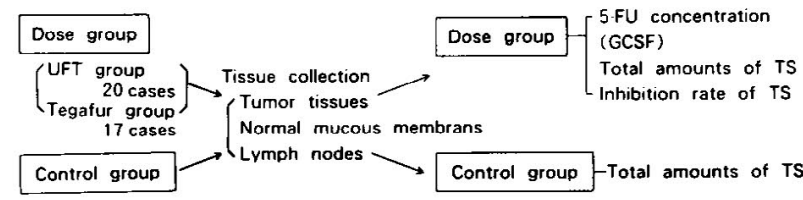

Fig.1 Materials and methods Case with colorectal calcinoma : 48 cases (Dose group : 37 cases. Control group : 11 cases)

day) before the surgeries. Tumor tissues, mucous membranes in normal areas, and regional lymph nodes were collected at the time of surgeries. Tissues were frozen and stored. 5-FU concentration, total amount of TS and inhibition rate of TS in various tissues were measured. Twenty cases received UFT, 17 cases received Tegafur, and these two groups were compared. Eleven cases did not receive any drug. Various tissues were collected from these 11 patients as well at the time of surgeries, and total amounts of TS were measured. Total amounts of TS were compared between dose group and control group. Statistical analysis was done by $\mathrm{t}$-test, and statistical significance was determined by a risk rate less than $5 \%$.

\section{Procedures}

5-FU concentrations in tissues were measured by Gas Chromatographic Mass Fragmentgraphic Method (GCMF) according to Marunaka ${ }^{8}$.

TS was measured according to a modified method by Spears et al. ${ }^{9)}$, total amounts of TS \& free TS were measured, and inhibition rate of TS (\%) was calculated by the following formula. 


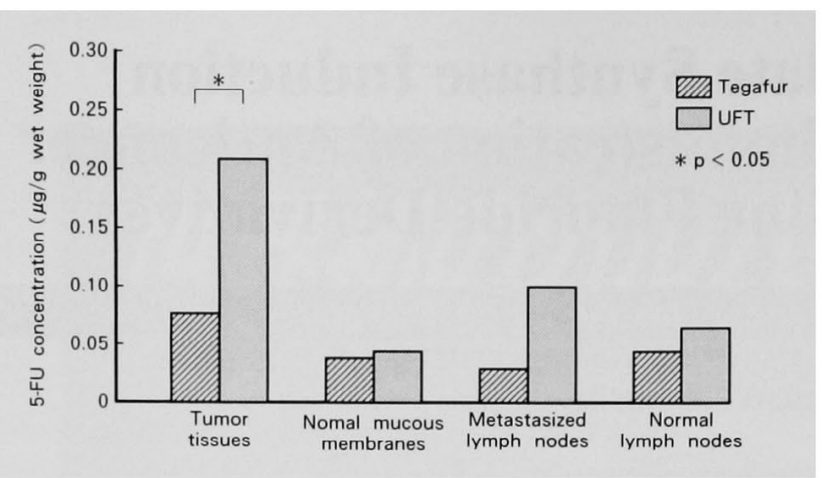

Fig. 2 5-FU concentrations after UFT or Tegafur administration

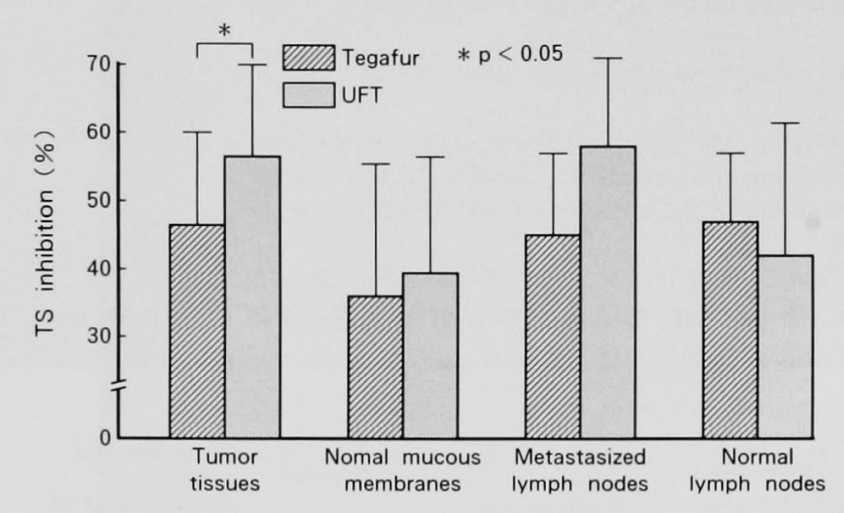

Fig.3 Inhibition rate of TS after UFT or Tegafur administration

Inhibition rate of TS $(\%)=\frac{\text { TS total }- \text { TS free }}{\text { TS total }} \times 100$

Results

Comparison of 5-FU concentrations among dose groups (Fig.2)

5-FU concentrations in tumor tissues were $0.208 \pm$ $0.143 \mu \mathrm{g} / \mathrm{g}$ among UFT group, and $0.077 \pm 0.027 \mu \mathrm{g} / \mathrm{g}$ among Tegafur group. UFT group showed significantly higher 5-FU concentration $(\mathrm{P}<0.05)$. 5-FU concentrations in metastasized lymph nodes were 0.101 $\pm 0.075 \mu \mathrm{g} / \mathrm{g}$ among UFT group, and $0.032 \pm 0.004 \mu$ $\mathrm{g} / \mathrm{g}$ among Tegafur group. UFT group showed higher 5FU concentration, but no statistical significance was detected. No difference was seen in normal mucous membranes and non-metastasized lymph nodes between two groups.

Comparison of inhibition rate of TS among dose groups (Fig.3)

Inhibition rates of TS in tumor tissues were $56.12 \%$ among UFT group, and $45.52 \%$ among Tegafur group. UFT group showed a significantly higher inhibition rate $(\mathrm{P}<0.05)$. UFT group showed a higher inhibition rate of TS in metastasized lymph modes $(57.45 \%)$, but no statistical significance was detected. Inhibition rates of TS in normal mucous membranes were $39.0 \%$ among UFT group, $38.3 \%$ among Tegafur group, and no

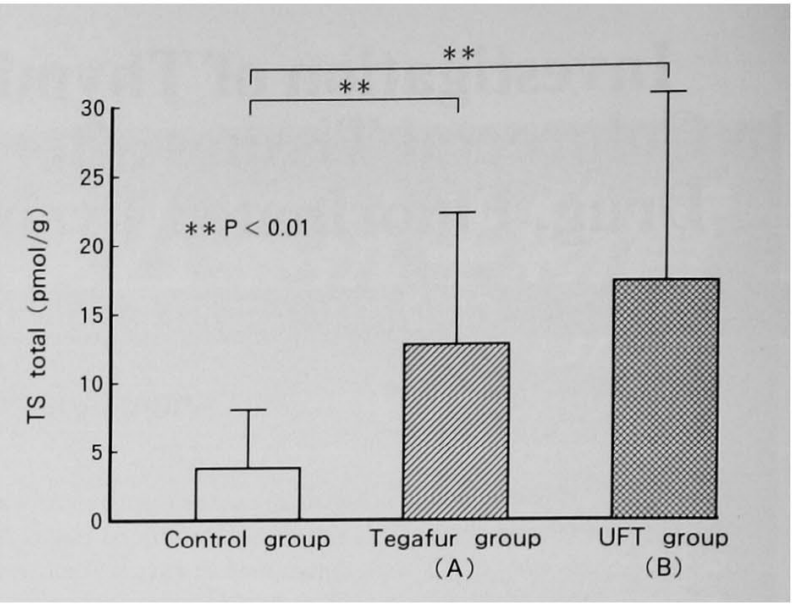

Fig. 4 Total amounts of TS in tumor tissues

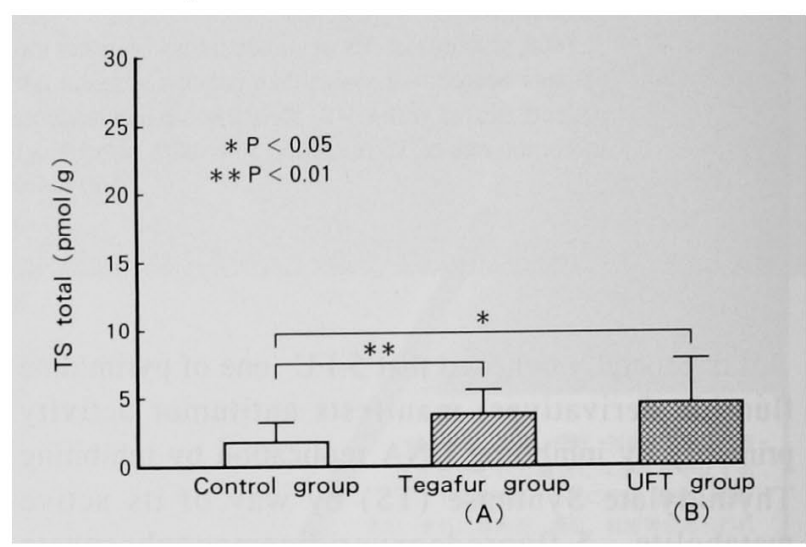

Fig.5 Total amounts of TS in normal mucous membranes

statistical significance was detected.

Comparison of total TS in tumor tissues (Fig.4)

Total TS in tumor tissues were $16.35 \pm 13.15 \mathrm{pmol} / \mathrm{g}$ among UFT group, $11.90 \pm 9.84 \mathrm{pmol} / \mathrm{g}$ among Tegafur group, and $4.95 \pm 5.96 \mathrm{pmol} / \mathrm{g}$ among control group. Therefore, UFT showed approximately 3.3 times higher total TS than control group. Tegafur group showed approximately 2.4 times higher total TS than control group, and both UFT group and Tegafur group showed statistically higher total TS.

\section{(Fig.5)}

Total TS in normal mucous membranes were $4.80 \pm$ $3.05 \mathrm{pmol} / \mathrm{g}$ among UFT group, $3.52 \pm 1.63 \mathrm{pmol} / \mathrm{g}$ among Tegafur group, and $1.52 \pm 1.35 \mathrm{pmol} / \mathrm{g}$ among control group. Therefore, both UFT and Tegafur groups showed significantly higher total TS than control group.

\section{Comparison of total TS in lymph nodes (Fig.6)}

Total TS in lymph nodes were $13.61 \pm 11.0 \mathrm{pmol} / \mathrm{g}$ among UFT group, $6.43 \pm 3.86 \mathrm{pmol} / \mathrm{g}$ among Tegafur group, and $2.43 \pm 3.70 \mathrm{pmol} / \mathrm{g}$ among control group. Therefore, both UFT and Tegafur groups showed higher 


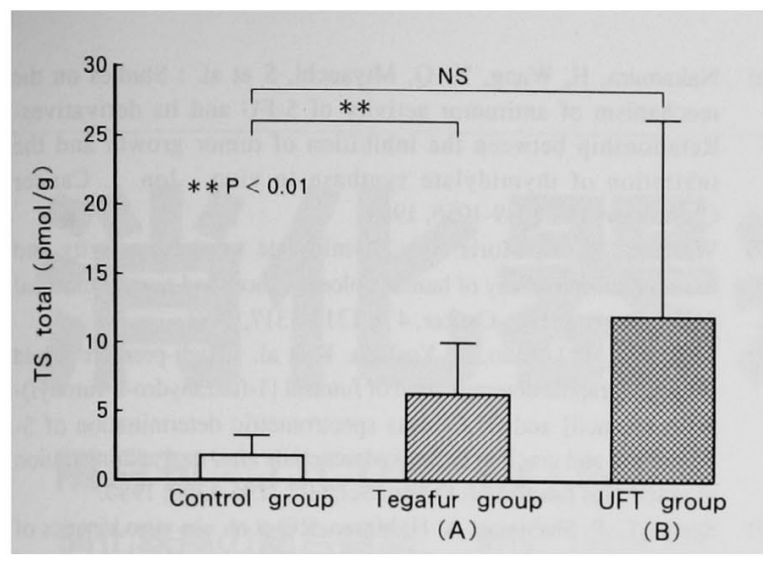

Fig. 6 Total amounts of TS in lymph nodes

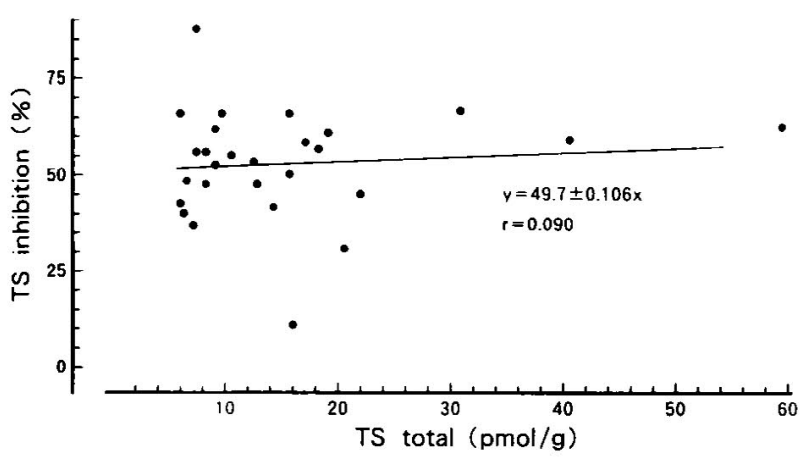

Fig.7 Relationship between total amounts of TS and inhibition rate of TS in tumor tissues

total TS than control group, but statistical significance was not detected.

Relationship between total TS and inhibition rate of TS in tumor tissues (Fig.7)

Inhibition rate of TS was 50 to $60 \%$ regardless of total TS.

\section{Discussion}

Principle chemotherapeutic drugs against gastrointestinal carcinoma are pyrimidine fluoride derivatives, and UFT is one of the most widely used drugs in this country. Colorectal carcinoma is not as sensitive to chemotherapy as gastric carcinoma. Therefore, various chemotherapeutic drugs have been searched for presently. The authors investigated 5-FU concentrations and inhibition rates of TS in tissues after administration of UFT in patients with colorectal carcinoma, and reported that higher 5-FU concentrations and significantly higher inhibition rate of TS were achieved after administration of UFT as compared with administration of Tegafur ${ }^{11)}$. This study was conducted, based on the previous results. From the standpoint of responsiveness to drugs, UFT may have a component which is responsible for more potent antitumor activity against colorectal carcinoma than Tegafur.
Additionally, Takashima et al. ${ }^{12)}$ compared Tegafur and UFT as supplementary chemotherapeutic drugs after resection of colorectal carcinoma and reported that higher 5-year survival rate was achieved among UFT group. In the near future, UFT will be a main chemotherapeutic drug against colorectal carcinoma.

Generally, primary mechanism of antitumor activity of pyrimidine fluoride at clinical doses is believed to be by inhibition of DNA replication ${ }^{6)}$. Details of the mechanism can be summarized as follows. $5-\mathrm{FU}$ is taken up in tumor tissues, 5-FU is converted to FdUMP in tumor cells, FdUMP-TS-methylene hydrofolate (MeTHF) binds, and then ternary complex is formed. TS activity will be inhibited by this ternary complex, DNA replication will be inhibited, and eventually anti-tumor effects will be manifested ${ }^{13)}$. What kinds of effects may pyrimidine fluoride have on TS in tissues? It has been reported that TS was induced in tumor tissues after the administration of pyrimidine fluoride from basic science studies ${ }^{6}$, but no paper has been published regarding clinical aspects. Therefore, we investigated TS activity clinically after the administration of UFT or Tegafur in patients with colorectal carcinoma, and found that TS was highly induced by UFT of Tegafur. In tumor tissues, TS was induced approximetely 3.3 times higher in UFT group, and approximately 2.4 times higher in Tegafur group than control group. In normal mucous membranes, TS was induced approximately 3.2 times higher in UFT group, and approximately 2.3 times higher in Tegafur group than control group. The mechanism of TS induction by pyrimidine fluoride may be due to simple compensatory reactions in vivo, but details are unclear. Washtien ${ }^{14)}$ speculated that TS gene was amplified, but further basic studies may be necessary. Additionally, induction of TS and increase of total TS may not necessarily cause higher inhibition rate of TS, since our present data showed that inhibition rate of TS remained 50 to $60 \%$ regardless of total TS. This level of inhibition may be the limitation by administration of clinical doses ( 400 to $600 \mathrm{mg} /$ day) of UFT alone. Recently, many papers have been published regarding enhanced antitumor effects by combination of 5 -FU\&CDDP ${ }^{15 \sim 17)}$ or Leucovorin ${ }^{18 \sim 19)}$. Shirasaka et $\mathrm{al}^{20)}$ elucidated mechanism of synergistic effect by 5-FU and CDDP from basic studies. Briefly, they reported the following findings. CDDP manifests antitumor effects by inhibiting transport of methionine into cells. Since folic acid metabolism is coupled with methionine metabolism, folic acid metabolism is also influenced by CDDP during transport process. Namely, reduced folic acids such as Me-THF, intermediary metabolites of folic acids, accumulate in tissues, which supplement Me-THF that was used up for ternary complex formation. 
Therefore, ternary complex can be formed easily, which may in turn amplify antitumor effects of 5-FU. Our clinical studies did not correlate increase of total TS with inhibition rate of TS. It could be due to depletion of MeTHF, but in order to prove this theory, determination of TS as well as Me-THF may be required ${ }^{21)}$. Suga et al ${ }^{22)}$ performed combination therapy consisting of UFT and CDDP in patients with gastric cancer, and found that combination therapy was very effective in case of gastric cancer. Colorectal carcinoma is dependent on TS and so it may respond to inhibition of TS sensitively? Therefore, UFT may be an effective chemotherapeutic drug for the treatment of colorectal carcinoma.

\section{Conclusion}

5-FU concentration and inhibition rate of TS in tissues were compared after repeated administration of UFT or Tegafur in patients with colorectal carcinoma. As a control, we tested cases who never received any drug. Total TS in tissues was monitored after the administration of UFT or Tegafur.

1) In tumor tissues, significantly higher 5-FU concentration and inhibition rate of TS were detected among UFT group than Tegafur group.

2) Significantly higher total TS was detected after the administration of UFT or Tegafur. Particularly, the effect was more remarkable among UFT group.

3) In tumor tissues, There was no correlation between total TS and inhibition rate of TS. Inhibitory rate of TS and inhibition rate of TS. Inhibitory rate of TS was 50 to $60 \%$ regardless of total TS.

\section{References}

1) Cohen, S S, Flaks, JG., Barner, M D et al. : The mode of action of 5fluorouracil and its derivatives. Proc. Natl. Acad. Sci. USA, 44 : 1004-1012, 1958.

2) Fujii, S, Ikenaka, $K$, Shirasaka, $T$ et al. : Effect of Uracil and its derivatives on antitumor activity of 5-fluorouracil and 1-(2tetraphydrofuryl)-5-fluorouracil. Gann, $69: 763-772,1978$ ).

3) Arima, S, Futami, K, Shigeta, $M$ et al. : 5-FU concentration in the blood and tissue of patients with gastric and colorectal cancer after administration of UFT or Tegafur. Jpn. J. Cancer Chemother, 13 : 2618-2624, 1986.

4) Suzuki, M, Sekiguchi, I, Tamada, T et al. : Level of inhibition of thymidylate synthase activity and 5-fluoruracil in tumor tissues after administration of UFT or Tegafur. J. Jpn. Soc. Cancer Ther, 24 : 1399.1404, 1989.

5) Sakamoto, S, Kudo, H, Kuwa, K et al. : Effects of neo-adjuvant chemotherapy with UFT (A combination of tegafur and Uracil) on DNA-synthesizing enzyme activities in human colorectal carcinomas. J. Jpn. Soc. Cancer, Ther, $24: 94-98,1989$.
6) Nakamura, H, Wang, $Y$ Q, Miyauchi, $S$ et al. : Studies on the mechanism of antitumor activity of 5-FU and its derivativesRelationship between the inhibition of tumor growth and the inhibition of thymidylate synthase in vivo. Jpn. J. Cancer Chemother, $11:$ 1049-1056, 1984.

7) Walberg, $\mathrm{W} \mathrm{H}$, Moris. J. : Thymidylate synthase activity and fluorouracil sensitivity of human colonic cancer and nomal mucosal tissues preparations. Cancer, $47: 1313-1317,1981$.

8) Marunaka, T, Umeno, Y, Yoshida, $K$ et al. : High-pressure liquid chromatographic determination of futraful [1-(tetrahydro-2-furonyl)5-fluorouracil] and GLC-Mass spectrometric determination of 5flurouracil and uracil in biological materials after oral administration of uracil plus futraful. J. Pharm. Sci, $69:$ 1296-1300, 1980.

9) Spears, C P, Shabinian, A H, Moran, RG et al. : In vitro kinetics of thymidylate synthase inhibition in 5-fluorouracil sensitive and resistant murine colon adenocarcinoma. Cancer Res, 42 : 450-456, 1982.

10) Takeda, S, Uchida, J, Yamada, Y et al. : The significance of measuring inhibition of thymidylate synthase activity as a parameter for antitumor activity of 5-fluorouracil derivatives. Jpn. J. Cancer Chemother, $15: 2125-2130,1988$.

11) Futami, $K$, Arima, $S$, Yoshimura, $S$ et al. : Drug concentration in cancerous large bowel tissue and thymidylate synthase inhibition rate after administration of tegafur and UFT. Jpn. J. Cancer Chemother, 18 : 215-220, 1991.

12) Takashima, S, Tomita, F, Saito, H et al. : Clinical effect of postoperative adjuvant chemotherapy for advanced colorectal cancer-Comparisons of tegafur and UFT-. Jpn. J. Cancer Chemother, 18 : 2315-2323, 1991.

13) Oie, S, Okabe, H, Takeda, S et al. : Analysis of the mechanism of increased antitumor activity of UFT after combined treatment with CDDP. Jpn. J. Cancer Chemother, $17: 1321-1326,1990$.

14) Washtien, WL : Increased levels of thymidylate synthase in cells exposed to 5-fluorouracil. Mol, Pharm, 25 : 171-177, 1983.

15) Cantrell J E, Hart, R D, Tayler, R F et al. : Pilot trial of prolonged continuous infusion 5-FU and weekly cisplatin in advanced colorectal cancer. Cancer Treat. Rep, $71: 615-618,1987$.

16) Cohn, J, Tester, W, Deszi, A et al. : Continuous infusion 5fluorouracil and weekly low dose cisplatin in metastatic gastrointestinal malignancies. Proc. Am. Soc. Clin. Oncol, 7: 115, 1988.

17) LoRusso, P, Pazdur, R, Redman, B. G et al. : Low-dose continuous infusion 5-fluorouracil and cisplatin : Phase - evaluation in advanced colorectal carcinoma. Am. J. Clin. Oncol, 12 : 486-490, 1989.

18) Petrelli, N. P, Herrera, L, Rustum, $Y$ et al. : A prospective randomized trial of 5 -fluorouracil versus 5 -fluorouracil and highdose leucovorin versus 5 -fluorouracil and methotrexate in previously untreated patients with advanced colorectal carcinoma. J Clin. Oncol, $5:$ 1559-1565, 1987.

19) Sasaki, T, Ota, K, Sakata, $S$ et al. : High-dose leucovorin and 5fluorouracil in advanced gastric and colorectal cancer-High dose leucovorin and 5-FU study group-. Jpn. J. Cancer Chemother, 17 : 2361-2368, 1990.

20) Shirasaka, T, Shimamoto, $Y$, Kinoshita, $H$ et al. : Mechanism for synergistic antitumor effect in the combination of 5-fluorouracil with cisplatin in vivo tumor models : from the view of biochemical modulation of 5-fluorouracil. Jpn. J. Cancer Chemother, $18: 403$ $409,1991$.

21) Spears, C P, Gustarsson, B G, Berne, M et al. : Mechanism of innate resistance to thymidylate synthase inhibition after 5-fluorouracil. Cancer Res, $48: 5894-5900,1988$.

22) Suga, S, Kimura, R, Nagai, $\mathrm{H}$ et al. : An eval uation of gastric cancer given UFT/CDDP chemotherapy. Jpn. J Cancer Clin, 37 : 829-839. 1991.

Offprint request to : K Futami, Department of Surgery, Chikushi Hospital, Fukuoka University, 377-1 Zokumyoin, Chikushino City, Fukuoka 818, Japan 


\section{Ann Cancer Res Ther}

HLA Antigens and Postoperative Adjuvant Immunochemotherapy in Gastric Cancer ; a Multidimensional Data Analysis

p 95 99

\section{Kyoji Ogoshi}

癌治療を行う前に，効果のある，患者個人個人に最適 な治療法の予測が可能であれば，癌患者のquality of life （QOL）の向上に役立つものと考えられる。そこで，本 研究では，個人を同定出来るHLA抗原を用いて，個人個 人の治療法が予測できないかどうか検討を行った。

[対象と方法] 対象患者の術前にmicrocytotoxicity assayを用いてHLA-A，-B，-C抗原を測定した。 HLA抗 原の分類は，胃癌切除例429例を対象とし，数量化而類 ${ }^{11}$ 13)を用いて四つの型に分類した。予後因子の検討は，胃 切除術単独90例，胃切除術+化学療法98例，胃切除術+ PSK併用免疫化学療法133例を対象として, Coxの比例八 ザードモテルを用いて解析した。

[結 果] (1) 数量化四類により，1型はA-3,Aw19, Aw-33, B-12, B-44, Bw-56, B-35抗原，2型はAw31，B-5, B-51，B-13，Cw-4抗原，3型はA-2，A-9, Bw52, B-7, B-15, Bw-62, B-16, B-39, В-40, Вw-60, Bw-48, Cw-7抗原，4型はA-10，A-11，Bw-22，Bw-54, Bw-55, Bw-61, Bw-46, Bw-59, Cw-1，Cw-3抗原に分 類された（図1）。

(2) 単一予後因子としての年㱓は49歳以下の患者が最 も予後良好で，60歳以上の患者との間，進行度では， pTNM stage 1Aの患者がもっとも予後良好で, stage 2, 3A，3B，4の患者との間，治療法別では，PSK併用免疫 化学療法群がもっとも予後良好で, 胃切除群との間, HLA分類型は，3型が最も予後良好で，1型との間に有意 差を認めた（表2）.

(3)多因子での検討では，HLA抗原型4型でPSK併用 免疫化学療法施行群が最も予後良好で，1型，2型，3型 の胃切除群，1型の化学療法施行群に比し有意に予後良 好であった（表3）

[考 察] われわれは，術前のシアル酸が異常值を 示す症例，または血清IAP (immunosuppressive acidic protein）值が異常值を示し，脾铖摘出がなされた症例で は, 術後PSK併用免疫化学療法が最適な治療法であるこ とを報告した ${ }^{14,15)}$ 。一方，個人を同定出来るHLA抗原を 用いて検討を行ったところ，HLA-Bw-40抗原陽性胃癌患 者のPSK併用免疫化学療法施行例は予後良好であっ た ${ }^{32)}$ 。しかし，HLA抗原はその特徵として多様性を示す ことが知られている．そこで，本研究では，数量化正類 を用いてHLA抗原の発現頻度からHLA抗原を群として分 類し，治療法と予後を検討したところ，HLA抗原のパ ターンと治療法により予後が異なっていた。このことは HLA抗原のパターン（そのようなHLA抗原を持っている 患者）に相対する最適な治療法が存在することを示して いるものと考えられる.よって，癌患者のHLA抗原の測 定は，個人個人の最適な治療法の予測に有用であると考 えられた。
Investigation of Thymidylate Synthase Induction in Colorectal Tissues after Administration of Anticancer Drug, Fluorinated Pyrimidine Fluoride Derivatives

p 101 104

Kitaro Futami et al.

大腸癌に対してUFTならびにTegafurの術前投与を行 い，組織内 $5 F u$ 濃度およびTS阻害率を比較検討するとと もに，薬剤非投与例をコントロールとして，抗癌剤投与 による組織内TSの変動についても検討を加えた。

[対象と方法］ 大腸癌切除症例48例を对象とした。 37例は薬剤投与例（UFT投与群20例, Tegafur投与群17 例）であり，術前7日間抢のおの $600 \mathrm{mg}$ ，分 3 とし経口連 続投与を行った。手術時, 腫瘍組織，正常部粘膜，リン パ節（1群領域）を採取し，凍結保存ののち各組織にお ける5Fu濃度，TS量，TS阻害率を測定し，UFT群と Tegafur群を比較した。また，11例の薬剤非投与例につい ても各組織のTS量を測定し, 薬䯇投与群と比較した。

[結 果] 薬剂投与群における5Fu濃度の比較では 腫瘍組織においてUFT群がTefagur群に比し，有意に高值 であった。また，TS阻害率についてもUFT群で有意に高 い阻害率を示した。各組織におけるTS量については， UFT群, Tegafur群とも薬剂非投与群に比較し, 有意に高 いTS量を示し，UFT群でより顕著であった。腫瘍組織に おけるTS量とTS阻害率の関係をみると，TS量に関係な く，TS阻害率は50〜60\%の值であった。

[ 考 察] 術前 1 週間連投による組織内 $5 \mathrm{Fu}$ 濃度およ びTS阻害率の検討を行い，腫瘍組織においてUFT群で Tegafur群に比し有意に高い值を示し，大腸癌に対しても UFTが上り強い抗腫瑒効果を期待しうる因子を備えてい ると考えられた，抗癌剂による組織内TSの変動について は，腫慯組織において非投与群にくらべUFT群て3.3倍, Tegafur群で2.4倍, 正常粘膜でもおのおの3.2倍, 2.3倍の TS誘導が生じていた，しかしながら，TS量に関係なく TS阻害率は50〜60\%に留まっていた，この程度の值が䠛 床投与量におけるUFT単独投与の限界とも考えられる。

最近の知見にて，5FuとCDDPあるいはLeucovorin併用 効果のメカニズムが解明されている．5FuのDNA合成障 害に最も重要となるFdUMP-TS-met-hylen hydrofolate (Me-THF) のternary complex形成の上で不足したMeTHFがCDDP代謝過程で補れることにより，ternary complex 形成が促進され相乗効果を発揮することが証明 されている，今回のTS量が増えても，阻害率に反映しな いという秸果もその原因をMe-THF枯渴に求めることも できるが，今後TSだけでなく，Me-THFの検索が必要で あろう。

大腸癌は胃癌にくらべ，TSにより強く依存し，TS阻害 により感受性が高いとも考えられており，薬剂側因子か らみて大腸癌に対してもTegafurにくらべTSの誘導が強い UFTの効果が期待されるところである. 